\title{
Marketing mix of Nagarjuna fertilizers and chemical limited in Buldana district
}

\author{
PRADEEP M. BAGADE, N.M. THAKER AND PRIYANKA D. GHATE
}

Received : 07.07.2017; Revised : 27.08.2017; Accepted : 11.09.2017

\begin{abstract}
Agriculture which accounts for one fifth of GDP provides sustenance to two-thirds of our population. Besides, it provides crucial backward and forward linkages to the rest of the economy. Successive five year plan have laid stress on selfsufficiency and self-reliance in food grains production and concerted efforts in this direction have resulted in substantial increase in agriculture production and productivity. Fertilizer sector was very crucial for Indian economy because it provides a very important input to agriculture. The fertilizer industry in India has played a pivotal role in achieving self-sufficiency in food grains as well as in rapid and sustained agriculture growth. India is the third largest producer and consumer of fertilizer in world after China and USA. India is the third largest producer and consumer of fertilizers in the world after China and USA, and contributes about 11.4 and 11.9 per cent to the total world production/consumption of NPK nutrients, respectively. However, in terms of consumption per hectare, the consumption of India (104.5 kg per hectare) is lower than neighboring countries, showing scope of further increase. The consumption of chemical fertilizer in India by and large was stagnant from 2001-02 to 2003-04. However, it has increased during the last two years; consumption during 2010-11 was 243.40 lakh metric tons (LMT) of NPK nutrients which is the highest ever achieved. The Urea, Diammonium phosphate, ammonium sulphate used to provide NPK and a rapid sustained agricultural growth and development of various agronomical and horticulture crops, and they are also useful in all crops. The importance of the fertilizer sector in India need hardly be emphasized as it provides a very vital input for the growth of Indian agriculture. Therefore fertilizers are mostly preferred by farmers. The present study is undertaken to the existing Marketing mix of Nagarjuna Fertilizers and Chemical Limited in Buldana district, farmers and dealers expectations from company and constraint in marketing of Fertilizers in Buldana district. Five tehsils were selected from purposively selected Buldana district for selection of respondents. From each selected tehsil randomly seven dealers for all talukas were selected. From each tehsil thirty four farmers were selected randomly. So finally total sample size of dealers 35 and farmers 170 were selected.
\end{abstract}

KEY WORDS : Marketing mix, Nagarjuna fertilizer, Chemical, GDP

\footnotetext{
MEMBERS OF THE RESEARCH FORUM

Correspondence to:

PRADEEP M. BAGADE, Post Graduate Institute of Agri-Business

Management, Junagadh Agricultural University, JUNAGADH (GUJARAT) INDIA
}

Authors' affiliations:

N.M. THAKER AND PRIYANKA D. GHATE, Post Graduate Institute of Agri-Business Management, Junagadh Agricultural University, JUNAGADH (GUJARAT) INDIA
How to cite this paper : Bagade, Pradeep M., Thaker, N.M. and Ghate, Priyanka D. (2017). Marketing mix of Nagarjuna fertilizers and chemical limited in Buldana district. Internat. J. Com. \& Bus. Manage, 10(2) : 157-168, DOI: 10.15740/HAS/IJCBM/10.2/157168. 